\title{
Management Development for Women Entrepreneurs in the SME Sector of Bangladesh
}

\author{
Md. Alamgir Jali1 ${ }^{*}$, Fatema Roksana ${ }^{2}$, Md. Jahangir Alam ${ }^{3}$ \\ ${ }^{1}$ Lecturer in Accounting, Kushtia Govt. College, Kushtia, Bangladesh, \\ ${ }^{2}$ Lecturer in Economics, Amla Govt. College, Mirpur, Kushtia, Bangladesh, \\ ${ }^{3}$ Student of BBA, Dept of Management, University of Rajshahi, Bangladesh.
}

\begin{abstract}
The paper strives to analyze the management practices to realize the necessity of management development for women entrepreneurs in SME sector. This study shows the necessity of management development for enhancing competitive efficiency and effectiveness of women entrepreneurs in the SME sector of the developing economy of Bangladesh. Integrated Management Process, Risk Management and Credit Control, Productivity Management, Quality Management, Sales Management, Human Resource Management, Business Process Improvement, Health and Safety Measures and Social Responsibility are considered as the parameters to comprehend practice pattern of management development tools. Qualitative discussion along with quantitative analysis detects the necessity as well as the significance of management development for women entrepreneurs in the SME sector in Bangladesh.
\end{abstract}

Keywords: Management Development, Small \& Medium Enterprise (SME), Women Entrepreneurship, Performance, Effectiveness and Efficiency.

\section{Introduction}

Bangladesh, a forty two year old torpidly developing country, has been suffering from various problems since independence. The country came to the world map by proving its capability from a sanguinary war,has obviously a ubiquitous valor to evolve. But, it lagged behind and crucially identified as a developing country. Why not a developed country? The answer is known to all, that human is the potential resource of this country but outmoded management practice directs toward an infernal region, which is anunder developed zone. Any resource with poor management can't be actually a resource and worthless like sessile anther. The management practice of this country deserves required but not desired development to all the sectors particularly business and administration.

Small and Medium Enterprise $(\mathrm{SME})^{1}$ is one of the thirst sector that deserves management development besides investment. Women entrepreneurs ${ }^{2}$ are playing an irrefutable role unremittingly to the economy of Bangladesh contributing to GDP of 5.23\% (2011-12) ${ }^{3}$ and $5.27 \%(2012-13)^{4}$ with a growth of $6.45 \%(2011-12)$ and $6.76 \%(2012-13)^{5}$. It creates a lot of employment and abundant profit without practicing management properly. This is the time to unleash the potentials and to increase the skill for better performance. Then the success can be desired and deserved.In Bangladesh, women lag behind from man though male female ratio is 100.3: $100^{6}$, the work force contribution $29.94 \%$ of total domestic work force. Despite the actual situation of women entrepreneurs in Bangladesh is very dilapidated literacy rate of women is $54.8 \%$ compared to man $(61.10 \%)$.Statistics shows that, $86 \%$ of women entrepreneurs have not been introduced with proper training, $75 \%$ faces scarcity of raw materials, Lack of capital impedes $90 \%$, social barriers $95 \%$, and unsecured communication system $81 \%$, lack of efficient workers $60 \%$, sexual harassment $65 \%$, religious belief and social customs $71 \%$ and family restriction $45 \%$ of women entrepreneurs get blocked ${ }^{7}$.

The management development program encompassed with a training needs assessment and straightforward management training subjects, such as business planning, financial management and marketing (Prokopenko 1998). The researchers believe that business organization whether it is small or large must be well managed to ensure wealth maximization and sustainability.In this situation, women entrepreneurs in the SME sector are seeking for a convenient solution to grow faster with sustainable business. So, the researchers of this study think that application of management development tools maybe the celestial nymph of success for the women entrepreneurs in the SME sector of Bangladesh.

\section{Background}

Business is considered a common job for a large number of peoplein Bangladesh. The Economic Census, 2001-2003 data reveals that women own only $2.83 \%$ of all enterprises. Rural women are involved in livestock and farming, poultry rearing, rice husking, spice making, imitation ornament trading, pickle making and other micro businesses(Zaman\& Islam, 2011). Urban women are mostly involved in block printing and boutiques, bakery and fast food, doll making, tailoring, fabrics paint, interior decoration, etc. They are also 
owners of beauty parlors, computer training centers, leather goods, fish culture etc., which are non-traditional activities for women (Al-Hossienie, 2011).

But, women entrepreneurship and participation in business and decision making especially in small and medium enterprises hasincreasedin recent years. Women entrepreneurs prefer to start their business in sectors where female employees can be recruited. The choice of the sector is limited by various factors such as resource constraint, female aversion to risk-taking etc. which forces them to engage in activities with low entry barriers and low financial risks such as food processing and or clothing and textile sector (Sultana 2012).

In most of the cases, female businesses have smaller employment and sales than male businesses. Although some of them are sole proprietors,majority are small enterprisesemploying 5 to 20 persons (MIDAS ${ }^{8} 2009$ ). Participation of women as entrepreneurs has also improved the quality of their living standard and households. In fact, they serve as a role model for self-employment opportunities. Women enterprises are small in size. Short-term loans were more widely used than medium term loans, which had an average size of Tk. 3 lakh. The average interest rate was $13 \%$, ranging from $10 \%$ to $14 \%$. Loan giving process discriminates against women. The average time required for an SME to process loan was 57 days, while for women enterprises it took 145 days. Debt financing has yet to deeply penetrate women-led enterprises (Bangladesh Bureau of Statistics, 2007). Government of Bangladesh and a number of NGOs are operating lots of development programs to improve the SME sector.

In spite of these opportunities, this sector couldn't expand to the expected level. This sector should be developed more to increase employment and earnings.In Bangladesh, lots of study has been conducted on the development of women entrepreneurship in the small and medium enterprises. Some of them concentrated on the entrepreneurship development program and training. But, those studies didn't concentrate on the necessity and application of management development tools. That's why an intensive study on the management development of the women entrepreneurs is required for the overall development of SME sector of Bangladesh.So, the researchers wish to study on the necessity of management development and demonstrate the management competencies to achievethe organizational goal by performing job effectively and efficiently.

\section{Objectives}

Management Development is brought to the knowledge of entrepreneurs and managers in the SME sector for developing individuals, organizations, society and ultimately the national economy of Bangladesh. The management process requires progression to develop the parameters of management development (namely Integrated Management Process, Risk Management and Credit Control, Productivity Management, Quality Management, Sales Management, Human Resource Management, Business Process Improvement, Health and Safety Measures and Social Responsibility). Women entrepreneurship is one of the powerful and effective mechanisms to ensure management development of the SME sector. Management Development can accelerate this mechanism.The specific objectives of this study are as follows:

* Recognition of the pattern of management practice, theories and principles exercised by the women entrepreneurs in the SME sector of Bangladesh.

* Investigation of the necessity of the Management Development and Training for the women entrepreneurs in the SME sector of Bangladesh.

* Endowment with some recommendation to cultivate management development for women entrepreneurs in the SME sectors of Bangladesh.

\section{A brief review}

The concept of small business varies country to country. There is no recognized and generally accepted definition that distinguishes small business aswell as medium enterprise.Entrepreneurship is the process of discovering new ways of coalescing resources available.An entrepreneur is someone who organizes, manages, and undertakes the risks of a business or enterprise. In Bangladesh, small and medium enterprises(in case of manufacturing)are those which has an investment of less than 15 million(1.50 core) excluding land, factory building and other fixed assets. In case of trading and services small and medium enterprises are those where less than 25 employees are recruited ${ }^{9}$.Woman entrepreneur refers to the woman who owns and manages an enterprise to earn profit.

Management development is the well-thought-out and structured process by which managers enhance their skills, competencies and knowledge through formal or informal training and learning methods, to increase both individual and organizational performance. The effective management of small and medium enterprise is mostly perceived to be of critical importance to organizational success as well as national economic welfare (Syrett\&Lammiman 2003).

Performance of SME sector in Bangladesh is not good (Mazumder and Choudhury 2001), a hypothesis was established to chalk out the problems. Performance evaluation was prioritized to accomplish business success (Ahmed, K. and Chowdhury, T.A. 2009), but internal management was skipped. After that many 
authors conducted studies on the problems, though recommendation was given also. Investment and capital inadequacy problem came to the front. Sustainable business solution has been stressed (Agbeibor 2006). Training is one of the requirements for doing income generating activities effectively (Anwar 1992).

This is factual to realize but only operational training can't qualifies managers to do job effectively. Some managerial roles are to be played to do jobs effectively and efficiently. Government initiative and Bangladesh Bank's Small Enterprise Fund (SEF) played significant role to develop SME sector (Miah, 2007). Involvement of women entrepreneurs in economic activities particularly in SME sector is needed, not only for their own development but also for the overall economic growth of the country. Socio economic impact of women entrepreneurship is keeping them well (Al-Hossienie, 2011) but proper learning and execution of management principles, training, and management development in sum integrated management system can develop this sector more than that of present. In the modern day economy, managerial skills for undertaking planning, marketing, and cash-flow management are vital for survival of a small and medium enterprise (Zaman\& Islam, 2011).

\section{Methodology}

This empirical study tries to see the sights of existing condition of the variables and relationship among them in a real world application of Bangladesh. Both qualitative and quantitative research approaches and procedures have been applied to explore applicable information for this study. A group of eight (08) members conducted the data collection stage by researcher's personal funding. Major stages, steps and procedures followed in this study were as follows:

\section{1. Sample Size}

A social survey was conducted through structured questionnaire among 68 women entrepreneurs of Rajshahi and Khulna City Corporation including BSCIC $^{10}$ areas. From Rajshahi area, 36 respondents and from Khulna area 32 respondents were interviewed by physical conversation.

\section{2. Respondents Selection}

There is no comprehensive directory for women entrepreneurs in surveyed areas; the respondents for questionnaire survey were intentionally selected for this research. Respondents, involved directly with management and decision making, were prioritized according to the objectives of the study.

\section{3. Data Sources}

In this research data were collected from primary and secondary sources. Primary source data were collected from individuals through direct (face to face) interviews, using a structured questionnaire ${ }^{11}$. Secondary sources of data include published books, journals, newspapers, articles, internet and concerned organizations have been used to enrich this study.

\section{4. Data Processing and Quality Control}

A cross checking mechanism was introduced to ensure the quality of data. Study team regularly monitored the data collection procedures. Collected data from fieldwork is reviewed properly. The collected data have been processed manually and paper in the present form has been prepared in order to make the study more informative, analytical and useful for the users. Tabular representations are made in MS Word and MS Excel.

\section{Findings of the Study}

The major findings from the questionnaire were divided into two parts. The first part entails the quantitative analysis. The quantitative analysis consists of tabular representation whereas second part entitles qualitative analysis which focuses the necessity of Management Development and training for the women entrepreneurs in the SME sector of Bangladesh.

\section{1. Quantitative Analysis:}

This section covers a comprehensive analysis consisting of major management tools used in organizational management. The analysis ${ }^{12}$ represents practice pattern of management tools in daily business operations and decision making process.

Integrated Management Process covers management principles, management functions, managerial rolesand leadership skills. Twelve practitioners are adept to practice these tools and their expertise helps to increase profit. Twenty three perpetrators have sensitive behavior on these areas. They are responsible for miscarriage of the organizational objectives due to lack of knowledge. Thirty threeof the respondents don't know about management (Table-1). 
Table 1: Practice for Integrated Management Process

\begin{tabular}{ccc}
\hline Execution Pattern & No. of Respondents & Percentage \\
\hline Practitioner $^{13}$ & 12 & $17.65 \%$ \\
Perpetrator $^{14}$ & 23 & $33.82 \%$ \\
Unable to Understand $^{\text {Total }}$ & 33 & $48.53 \%$ \\
\hline
\end{tabular}

As entrepreneurs have to undertake plenty of risk initially,risk management is required to reduce chance of loses. Sevenof the respondents who practice management can manage risk although they have not higher studies on risk management.Moreover, three respondents have no change after starting business. So, they manage risk cognitively. Twenty fiveof the respondents suffer increased risk. In addition,twenty two respondents face credit burden and 11 have no response due to lack of knowledge (shown in the table 2).

Table 2: Risk Management and Credit Control

\begin{tabular}{ccc}
\hline Risk Category & No. of Respondents & Percentage \\
\hline Risk Reduced & 07 & $10.29 \%$ \\
Remain Same & 03 & $04.41 \%$ \\
Risk Increases & 25 & $36.77 \%$ \\
Credit Burden & 22 & $32.35 \%$ \\
No Response & 11 & $16.18 \%$ \\
\hline Total & 68 & $100 \%$ \\
\hline
\end{tabular}

According to the survey report, productivity is not in fertile state. High productivity has been gained by repetitive job experience and management knowledge. Moderate and low productivity cases are also performed by experience. They have no proper training on productivity management (Table-3).

Table 3: Productivity Management

\begin{tabular}{ccc}
\hline Productivity Condition & No. of Respondents & Percentage \\
\hline High Productivity & 09 & $13.24 \%$ \\
Moderate Productivity & 32 & $47.06 \%$ \\
Low Productivity & 27 & $39.70 \%$ \\
\hline Total & 68 & $100 \%$ \\
\hline
\end{tabular}

In small and medium enterprise, entrepreneurs ensure product and service quality to increase the demand with little knowledgeon quality management.Rest of them has no particular knowledge on quality management (Table-4).

Table 4: Quality Management

\begin{tabular}{ccc}
\hline Quality Measures & No. of Respondents & Percentage \\
\hline Quality Ensured & 16 & $23.53 \%$ \\
Average Quality & 31 & $45.59 \%$ \\
No Response & 21 & $30.88 \%$ \\
\hline Total & 68 & $100 \%$ \\
\hline
\end{tabular}

Sales are managed cognitively from practical experience. Although, the entrepreneurs perform it well without any formal training, proper learning can increase the performance.Yet, three respondents use strategic sales techniques who learned by own effort (Table-5).

Table 5: Sales Management

\begin{tabular}{ccc}
\hline Sales Process & No. of Respondents & Percentage \\
\hline Strategic Sales & 03 & $04.42 \%$ \\
Traditional Sales & 43 & $63.23 \%$ \\
Low Sales & 22 & $32.35 \%$ \\
\hline Total & 68 & $100 \%$ \\
\hline
\end{tabular}

Human resource is managed by respondents' own techniques. Some of the techniques are analogous to the Human Resource Management though they have no institutional training. It is alarming that only six respondents practice with knowledge, rest of them doesn't know the term Human Resource Management (shown in the table-6). 
Table 6: Human Resource Management

\begin{tabular}{ccc}
\hline Skill Measures & No. of Respondents & Percentage \\
\hline Practice with Knowledge & 06 & $08.82 \%$ \\
Practice without Knowledge & 38 & $55.88 \%$ \\
No Knowledge & 24 & $35.30 \%$ \\
\hline Total & 68 & $100 \%$ \\
\hline
\end{tabular}

Women entrepreneurs improve their business organization by their own effort with and without proper knowledge. Many of them face deterioration of business because of inadequate knowledge (Table-7).

Table 7: Business Process Improvement

\begin{tabular}{ccc}
\hline Improvement Stage & No. of Respondents & Percentage \\
\hline Improved & 37 & $54.40 \%$ \\
Remain Same & 13 & $19.12 \%$ \\
Deteriorated & 18 & $26.47 \%$ \\
\hline Total & 68 & $100 \%$ \\
\hline
\end{tabular}

Health and Safety Measures are getting prioritized day by day. Respondents are conscious by knowing the impact from print and electronic media. They don't know the government regulation about this matter (Table-8).

Table 8: Health and Safety Measures

\begin{tabular}{ccc}
\hline Measures & No. of Respondents & Percentage \\
\hline Ensured Health \& Safety & 05 & $07.35 \%$ \\
Steps taken & 07 & $10.30 \%$ \\
Thinking about This & 13 & $19.12 \%$ \\
Not Important & 35 & $51.47 \%$ \\
No Responses & 08 & $11.76 \%$ \\
\hline Total & 68 & $100 \%$ \\
\hline
\end{tabular}

Small business enterprises don't make such a profit to involve mass social responsibility activities but some of them are active from management knowledge and religious viewpoint. Most of them have no knowledge about social responsibility (Table 9).

Table 9: Social Responsibility

\begin{tabular}{ccc}
\hline Measures & No. of Respondents & Percentage \\
\hline Responsible & 23 & $41.18 \%$ \\
Not Responsible & 07 & $10.30 \%$ \\
No Knowledge & 33 & $48.53 \%$ \\
Unable to Understand & 01 & $01.47 \%$ \\
No Responses & 04 & $05.88 \%$ \\
\hline Total & 68 & $100 \%$ \\
\hline
\end{tabular}

\subsection{Qualitative Analysis}

In recent years, women entrepreneurs are increasing significantly. They are involving with business and decision making for economic freedom. Women entrepreneurs have overcome the first stageof starting new venture and its management. But, proper management is yet to be established. In the quantitative analysis, we found that only $17.65 \%$ (Table 1)practice management properly and they are mostly benevolent by the management development.Moreover, only $10.29 \%$ can manage risk and $4.41 \%$ holds up by strain to impede risk from increasing (Table 2).However, high productivity comes to $13.24 \%$ of the entrepreneurs who practice management (Table 3). Only $23.53 \%$ entrepreneurs ensure quality to their product and service (Table 4)based on their experience and management knowledge. Strategic sales conducted by only $4.42 \%$ of the entrepreneurs who practice sales management whereas $63.23 \%$ habituated with traditional sales (Table 5).

As an essential management area, Human resource management is practiced with knowledge by $8.82 \%$ of the entrepreneurs and 55.88\% practices cognitively without proper knowledge (Table 6). In fact, 54.40\% of the entrepreneurs improved their business in less competitive areas but it will be very tough to survive in perfect competitive market without prior knowledge on business process improvement (Table 7). Health and safety measures without social responsibility don't relate directly to the operation of small business but health and safety measures can increase productivity and social responsibility activities can increase sales out of sight for marketing. Only $7.35 \%$ ensured health and safety measures (Table 8) and remarkably $41.18 \%$ shows responsibility to the society (Table 9). 
It is found in the survey that, she who knows the management performs well. In case of other variables, results articulate the scarcity of management development. Unfortunately, $48.53 \%$ entrepreneurs were unable to understand integrated management process, 36.77\% can't manage risk including $32.35 \%$ still suffers credit burden. These entrepreneurs also face low productivity $(36.77 \%)$, less quality product and service $(30.88 \%)$, low sales $(32.35 \%)$ with no knowledge on human resource management $(35.30 \%)$ and business process deterioration $(26.47 \%)$. In a sense, they are considered successful entrepreneur as they have started new venture successfully. It starts another battle to confront survival hostilities in this competitive business world.

\section{Recommendation \& Conclusion}

A number of Government and Non-government initiatives have already been made for women empowerment. Notwithstanding, application of management development tools for entrepreneurship are yet to come forward in our country for successful entrepreneurs as well as successful survivors. Government should play significant role by providing management development training to the women entrepreneurs in the SME sector. Non-government organization should take part for this pace.

The management development process should be segmented into five interactive parts. Firstly necessity of training should be assessed. Secondly,need based training program should be designed and implemented. Thirdly, a surveillance team should monitor the training program for women entrepreneurs. Then, actionsof the participants should be evaluatedafter successful completion of training. Poor performers should be taken for repeatingthe process.

The most important contributing factors for small enterprise were the introduction of management function, marketing techniques and the application of more advanced financial management techniques along with human resource management. Therefore, Management development devises a progressive effect on the business management practice especially of women entrepreneurs. The sagacity is that, as entrepreneurs and/or managers, they better apprehend and isolate integrated management process. The management practice should be designed according to business pattern and environment so that entrepreneurs can achieve a better connection with their business environment.

\section{Notes:}

1 "Small business is an enterprise that is comparatively small in size, operating in a geographically localized area except its marketing, employed fewer than 100 employees, and is financed by one individual or a small group of individuals" - Longeneckr, Moore and Petty (2000)

${ }^{2}$ A 'woman entrepreneur' was defined as a woman who has started a business, is actively involved in managing it, owns at least 50 percent of it, and has been in operation for a year or longer (Moore and Buttner, 1997).

${ }^{3}$ Bangladesh Economic Census, 2013

${ }^{4}$ Bangladesh Economic Census, 2013 [Quarterly Report]

${ }^{5}$ Bangladesh Economic Census, 2013 [Quarterly Report]

${ }^{6}$ Bangladesh Economic Census, 2013

${ }^{7}$ A Situation Analysis of Women Entrepreneurs of Bangladesh: Bangladesh Women Chamber of Commerce and Industry

${ }^{8}$ Micro Industries Development Assistance and Services, a resident representative from Netherlands

${ }^{9}$ Industrial Policy, 2010

${ }^{10}$ Bangladesh Small and Cottage Industries Corporations

${ }^{11}$ Questionnaire of this study was segmented in two parts; First part contains brief personal information, second part consists of specific queries about patterns of business management.

.$^{12}$ Based on primary data

${ }^{13}$ Practitioner is one who understands concern matters, knows practical application and expert to practice properly.

${ }^{14}$ Perpetrator is one who usually commits mistakes doing job because of limited knowledge or intentionally carries out unauthorized tasks. 


\section{Reference}

[1]. Ahmed, K. and Chowdhury, T.A. 2009, “Performance Evaluation of SMEs of Bangladesh”,International Journal of Business Management, Vol. 4, No. 7

[2]. Al-Hossienie 2011, Chowdhury Abdullah "Socio-Economic Impact of Women Entrepreneurship in Sylhet City, Bangladesh”, Bangladesh Development Research Working Paper Series, 12, P. 3.

[3]. Anwar S. Farhat 1992, "Management of Rural Women Entrepreneurs: The Case of Bangladesh", Journal of Business Administration Vol. 18, No. 3 \& 4, Dhaka.

[4]. Mazumder M. H. and T. R. Choudhury 2001 "Problems of Managing Small and Medium Enterprises in Bangladesh”, Bank Parikrama: A Journal of Banking and Finance, Vol. 26, No. 1, pp. 5-32.

[5]. Miah, Ayub 2007 "Small \& Medium Enterprise Sector Development Policies \& Programs", Dhaka, Bangladesh: Dhaka: SME Cell, Ministry of Industries (mimeo).

[6]. MIDAS 2009, “Women Entrepreneurs in SMEs: Bangladesh Perspective”, P.107 Available from: http://www.smef.org.bd/functions/dl_file.php?id=1\&file=../media/50/Women_Entrepreneurs_in_SMEs_ Bangladesh Perspective.pdf

[7]. Prokopenko, J. 1998, Management Development - A Guide for the Profession, Geneva: International Labour Office.

[8]. Sultana 2012, Afia, "Promoting Women's Entrepreneurship through SME: Growth and Development in the context of Bangladesh", Journal of Business and Management, Volume 4, Issue 1, PP 18-29.

[9]. Syrett, Michel and Lammiman, Jean 2003, Management Development, Capstone Publishing (Wiley Company)

[10]. Zaman, AKM Helaluz\& Islam, MdJahirul 2011, "Small and Medium Enterprises Development in Bangladesh: Problems and Prospects", ASA University Review, Vol.5 No.1, Dhaka. 